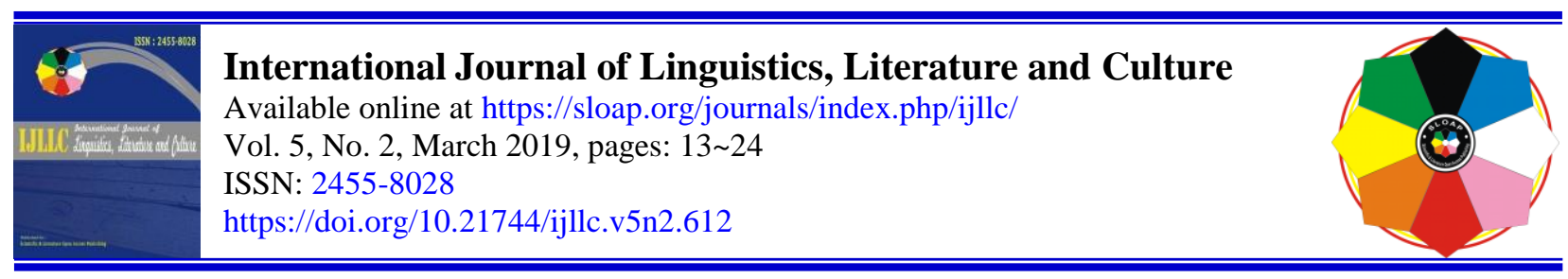

\title{
TEFL Methods in Indonesia
}

CrossMark

Yanrini Martha Anabokay a I Wayan Suryasa ${ }^{b}$

Article history:

Received: 27 September 2018

Accepted: 31 January 2019

Published: 30 March 2019

\section{Keywords:}

TEFL;

method;

teachers;

Indonesia;

descriptive;

Author correspondence:

Yanrini Martha Anabokay,

English Study Program

Universitas Persatuan Guru 1945 (UPG 45), NTT- Indonesia

Email address: anabokayrini@gmail.com

\begin{abstract}
The current research was a descriptive qualitative method that aimed to describe the TEFL methods applied by EFL teachers in Indonesia. Specifically, it aimed to know what the primary methods used by EFL teachers, how they delivered the methods, and what are the advantages and the disadvantages of applying the method in Indonesia case. The focus of the current research was on elementary teachers. Data were gained through interview and classroom observation. The research has shown that the primary methods used by EFL teachers were Grammar Translation Method and Direct Method. They combined those two methods and delivered them using English and Bahasa.
\end{abstract}

2455-8028 ${ }^{\circ}$ Copyright 2019. The Author. This is an open-access article under the CC BY-SA license (https://creativecommons.org/licenses/by-sa/4.0/) All rights reserved.

\section{Introduction}

English is one of the languages in the world which plays a very important role in communication for an international relationship (Echevarria et al., 2008). In the Indonesian education system, English is taught or learned compulsorily at all school from elementary up to senior high schools (Lauder, 2010). It aims to provide students with sufficient knowledge that can be used as a means to pursue their field of specialization at university and at work. The success of teaching the language in Indonesia, at one point, is based on the effective ways and methods.

The history of Teaching English as a Foreign Language (TEFL) itself, included in Indonesia, has been characterized by a search for more effective ways of teaching second or foreign languages (Salinas, 2006). For more than a hundred years, debate, and discussion within the teaching profession have often centered on issues such as the role of grammar in the language curriculum, the development of accuracy and fluency in teaching, the choice of syllabus frameworks in course design, the role of vocabulary in language learning, teaching productive and receptive skills, learning theories and their application in teaching, memorization and learning, motivating learners, effective learning strategies,

a English Study Program, Universitas Persatuan Guru 1945 (UPG 45), NTT- Indonesia

b STIKOM Bali, Department of Computer System, Denpasar, Indonesia ID 80226 Ph. +6281338734500 
techniques for teaching the four skills, and the role of materials and technology (Moussu \& Llurda, 2008). Although much has been done to clarify these and other important questions in English teaching, the teaching profession is continually exploring new options for addressing these and other basic issues and the effectiveness of different instructional strategies and methods in the classroom.

New approaches and methods proliferated throughout the twentieth century. Some achieved wide levels of acceptance and popularity at different times but were then replaced by methods based on newer or more appealing ideas and theories. As the approaches and methods are continually changed, then the practical things toward TEFL in Indonesia, we would say, is needed to be described as well, that is to contribute to the TEFL approaches development. On the thoughts, herewith we examined and described the English teaching methods in Indonesia as a phenomenon that occurred as it was (Mistar, 2005). The examination is hoped to be valuable inputs for the history of TEFL in the world where English is taught as a foreign language. Furthermore, the main aims of the current research were to know what the primary methods used by EFL teachers, how they delivered the methods, and what are the advantages and the disadvantages of applying the method in Indonesia.

\section{Materials and Methods}

The current research was descriptive qualitative research. We examined and described the TEFL methods in Indonesia in order to know what the primary methods used by EFL Teachers is, how they delivered the method, and what are the advantages and the disadvantages of applying the method in Indonesia case.

On gaining data, we used interview and observation techniques. The data were gained from EFL teachers of International School of NCIPS in Kupang, East Nusa Tenggara- Indonesia. First, we interviewed the teachers and then we did transcription. After that, we observed the TEFL in the classrooms. The last, we analyzed and described the findings. The description was based on the theory of teaching foreign language methodology proposed by LarsenFreeman (1986; 2008). She describes seven methods of teaching EFL namely Grammar Translation Method (GTM), The Direct Method, The Audio-Lingual Method, The Silent Way, Suggestopedia, Community Language Learning (CLL), and The Total Physical Response (TPR) (Cf. Richards et al., 2014).

\section{Grammar-Translation Method (GTM)}

Grammar- Translation Method is originally particular sets of procedures used in teaching Latin as a language which is not actively used in any community. Because of this method was used in teaching classical languages like Latin and Greek then it is known as the classical method (Larsen-Freeman, 1986: 4). Next, this method is directly adopted for teaching foreign languages all over the world with its primary emphases on written language literature. Richards et al., (2014: 3-4) describes the principles characteristics of the Grammar Translation Method are (1) the goal of foreign language study is to read its literature and translate the language into the target language. Therefore, grammar rules aspects are analyzed in detail; (2) reading and writing are the major focus. Speaking and listening get only little focus; (3) vocabularies are taught through bilingual word list; (4) the sentence is the basic unit of teaching and language practice; (5) accuracy is emphasized as a high standard in translation; and, (6) grammar is taught and be practiced by translating foreign text (Chang, 2011).

Grammar Translation dominated European and foreign language teaching from the 1840s to the 1940s, and in modified form, it continues to be widely used in some parts of the world today. At its best, as Howatt (1984), points out, it was not necessarily the horror that its critics depicted it as. Its worst excesses were introduced by those who wanted to demonstrate that the study of French or German was no less rigorous than the study of classical languages. This resulted in the type of Grammar-Translation courses remembered with distaste by thousands of school.

\section{The Direct Method}

The Direct Method is also known as the oral method due to its principles where the learners are expected to learn the target language directly as they learn their mother tongue. Speaking and listening are very important (Richards $e t$ al., 2014: 9). Furthermore, Larsen-Freeman (1986: 18), states that the name itself "Direct Method", is given due to the fact that in teaching-learning a foreign language meaning is directly connected to the target language without any translation to the learner's mother tongue. 
This Direct Method was developed as a reaction against the Grammar Translation Method which was considered lacking in communicative competence. Principles of this method are (1) mother tongue and translation are not used in the teaching-learning situation; (2) meaning should be communicated directly using actions and pictures to clarify meanings; (3) lesson begins with dialogues and anecdotes in conversational style; (4) reading and writing are taught after speaking; (5) literary text is read for pleasure; (6) no need to analyze the grammar of target language; and (7) the teacher must be able to speak like a native learners, for whom foreign language learning meant a tedious experience of memorizing endless lists of unusable grammar rules and vocabulary and attempting to produce perfect translations of stilted or literary prose.

\section{The Audio-Lingual Method}

This method puts more emphasis on mechanical repetition, the use of tape records, film strips, etc. Next, the principles of The Audio-Lingual Method, as written by Larsen-Freeman (1986: 43-45), namely (1) the goal of teaching is to use language communicatively; (2) the teacher is to lead, control and direct the students' behavior; and the students should follow the directions and respond as accurately, as rapidly as possible; (3) new vocabularies and structures are presented through dialogue (imitation, repetition, drill); (4) explicit grammar rules are not provided and culture information is contextualized in the dialogue; (5) most interaction is between teacher and students initiated by teacher; interaction between students is directed by the teacher; (6) the level of complexity of the speech is graded; selected from simple to more complicated and then put into habit forming; (7) pronunciation is taught from the beginning; (8) target language is used in the classroom; and (9) students' errors are to be avoided.

Castagnaro (2006), state that audio- Lingual methods consist of a list of grammatical items and constructions, often together with an associated list of vocabulary items. Notional-functional syllabuses specify the communicative content of a course in terms of functions, notions, topics, grammar, and vocabulary. Such syllabuses are usually determined in advance of teaching and for this reason, have been referred to as "a priori syllabuses."

\section{The Silent Way}

The Silent Way is a method of teaching foreign language using gestures, mime, visual aids, wall charts and wooden sticks of different lengths and color called Cuisenaire rods (Richards et al., 2014: 99). Through this method, the learners are expected to become independent in learning a foreign language. The Silent Way has more principles than other methods (Larsen-Freeman, 1986: 58-62). The principles are as follows;

[1] The students should start with something they have already known

[2] The teacher should give only what is needed

[3] Language is not learned by repeating after a model

[4] Students' actions can tell the teacher whether or not they have learned

[5] Students should learn to rely on each other and themselves

[6] The teacher works with the students while the students work on the other

[7] The teacher makes use of what students already know

[8] Learning involves transferring what one knows to a new context

[9] Reading is worked on from the beginning but follows from what students have learned to say

[10] Silence is a tool. It helps to exercise initiative. It also removes the teacher from the center of attention so the teacher can listen to and work with students

[11] Meaning is made clear by focusing on students' perceptions, not through translation

[12] Students can learn from one another; the teacher's silence encourages group cooperation

[13] When the teacher praises or criticizes students, it will impact students' development

[14] Errors are important and necessary for learning. They show the teacher what things are unclear

[15] Students need to learn to listen to themselves

[16] In the beginning, the teacher needs to look for progress, not perfection. Learning takes place in time. Students learn at different rates

[17] A teacher's silence frees the teacher to closely observe the students' behavior

[18] Students attention is the key to learning

Anabokay, Y., \& Suryasa, I. W. (2019). TEFL Methods in Indonesia. International Journal of Linguistics, Literature and Culture, 5(2), 13-24. https://doi.org/10.21744/ijllc.v5n2.612 
[19] Students should receive a great deal of meaningful practice without repetition

[20] Language's elements are introduced logically, expanding upon what students already know

[21] Students gain autonomy in the language by exploring and making choices

[22] Language is for self- expression

[23] Students learn how to accept responsibility for their own learning

[24] Some learning takes place naturally as we sleep. Students will naturally work on the days of the lesson

[25] The syllabus is composed of the linguistic structure

[26] The skills of speaking, reading, and writing reinforce one another

\section{Suggestopedia}

Suggestopedia is a method of teaching a foreign language developed based on "the suggestion on human behavior: Scientology" (Kharismawati, 2014). This is a belief that the brain; especially the right hemisphere, has great unused potential which can be exploited through the power of suggestion. This method has been developed to help students eliminate the feeling that they cannot be successful and also to help them overcome the obstacles of learning (LarsenFreeman, 1986: 72). Some principles underlying the Suggestopedia are as follows:

[1] Learning is facilitated in a comfortable and relaxed environment

[2] A student can learn from what is present in the environment

[3] The students will accept and retain information better if they trust and respect the teacher

[4] The teacher should recognize that learners bring certain psychological obstacles

[5] Activating the learner's imagination will aid learning

[6] The teacher should increase students' confidence that they will be successful learners. The more confident the students feel, the better they will learn

[7] Assuming new identity increases students' feeling of security and allows them to be more open

[8] The dialogue that students learn contains language they can use immediately

[9] Students will learn best when their attention is on the process of communicating

[10] The teacher should integrate indirect positive suggestions into the learning situation

[11] The teacher presents and explains grammar and vocabulary but not only focuses on them

[12] Meaning is made clear by mother tongue translation

[13] Communication takes place on "two planes": Conscious and subconscious. On the conscious plane, the learner attends; on the subconscious plane, the music suggests that the learning is easy and pleasant

[14] A pseudo- passive state, such as the state one experience when listening to a concert, is ideal for overcoming psychological barriers and for taking advantage of learning potential

[15] At this time, the distinction between the conscious and subconscious is most blurred or mixed, therefore optimal learning can occur

[16] Dramatization is a particularly valuable way of playfully activating the material. Fantasy reduces barriers to learning

[17] The fine art such as music, art, and drama enable suggestions to reach the subconscious. The arts should be integrated as much as possible into the teaching process

[18] The teacher should help students to activate the material to which they have been exposed

[19] Music and movement reinforce are the linguistic material

[20] In an atmosphere of play, the conscious attention of the learner does not focus on linguistic forms, but rather on using the language. Learning can be fun

[21] Errors are to be tolerated, the emphasis is on content, not form. The teacher should use the form a little later so the students will hear and used it correctly.

A most conspicuous feature of Suggestopedia is the centrality of music and musical rhythm to learning. Suggestopedia thus has a kinship with other functional uses of music, particularly therapy. Three functions of music in therapy: to facilitate the establishment and maintenance of personal relations; to bring about increased self-esteem 
through increased self-satisfaction in musical performance and to use the unique potential of rhythm to energize and bring order. This last function seems to be the one that Lozanov calls upon in his use of music to relax learners as well as to structure, pace, and punctuate the presentation of linguistic material.

Community Language Learning (CLL)

Community Language Learning is a method of teaching a foreign language in order to help learners use the target language communicatively (La Forge, 1971). The learning and teaching activities suggested in using this method are a translation, group work, recording, transcription, analysis, reflection, and observation, listening and free conversation. The principles underlying Community Language Learning are as follows:

[1] Building a relationship with and among students is very important

[2] Students will feel secure because their ideas of learning activities can be accepted. Here, students learn best when they feel secure

[3] Language is for communication

[4] This fosters interaction among students, rather than from student to teacher

[5] The teacher should be sensitive to students' limitations and not overwhelm them with more than they can handle

[6] Students feel secure when they know the limits of an activity

[7] Teacher and students are whole persons

[8] The teacher creates an accepting atmosphere

[9] The teacher should be a "counselor" to students. Teacher shows them that s/ he is really listening to them and understands what they are saying

[10] Students' native language is used in order to make the meaning clear because students will feel more secure when they understand everything

[11] The teacher should take responsibility for clearly structuring activities

[12] Learning at the beginning stage is facilitated if students attend to one task at a time

[13] The teacher encourages students' initiative and independence

[14] Students need quiet reflection time in order to learn

[15] Students learn best when they have a choice in what they practice

[16] Students need to learn to discriminate like perceiving the similarities and differences among the target language form

[17] In groups, students can begin to feel a sense of community. Cooperation, not competition is encouraged

[18] The teacher should work in a non- threatening way with what the learner has produced

[19] Developing a community among the class members builds trust and can help to reduce the threat of the new learning situation

[20] Learning tends not to take place when the material is too new or, conversely, too familiar

[21] In addition to reflecting on the language, students reflect on what they have experienced

[22] In the beginning stages, the "syllabus" is designed primarily by the students because they are more willing to learn when they have created the material themselves.

\section{The Total Physical Response (TPR)}

The Total Physical Response is a method of learning a foreign language due to its emphasis on listening comprehension which lets the learner responses to the TPR commands. Through orders and request, the students do whatever they are asked to do such as stand up, open the door, close the window, etc. According to Richards $e t$ al., (1086: 87), this method is a link to the "trace theory" of memory in psychology, which holds that the more often or the more intensively a memory connection is traced, the stronger the memory association will be and the more likely it will be recalled. In other words, this method helps the student to memorize the chunks of sentences of the target language by doing it in physical activity and producing verbal respond later on.

Principles of teaching underlying The Total Physical Response are (1) meaning in the target language can often be told through actions; (2) memory is activated through learner response; (3) students can initially learn one part of the

Anabokay, Y., \& Suryasa, I. W. (2019). TEFL Methods in Indonesia. International Journal of Linguistics, Literature and Culture, 5(2), 13-24. https://doi.org/10.21744/ijllc.v5n2.612 
language rapidly by moving their bodies; (4) the imperative is powerful linguistic device through which the teacher can direct student behaviors; (5) student can learn through observing actions as well as by performing the actions themselves; (6) it is very important that students feel successful; (7) students should not be made to memorize fixed routines; (8) corrections should be carried out in an unobtrusive manner; (9) students need to understand more than the exact sentences used in training; (10) language learning is more effective when it is fun; (11) spoken language should be emphasized over written language; (12) students will begin to speak when they are ready; and (13) students are expected to make errors when they first begin speaking and teacher should be tolerant of them.

\section{Results and Discussions}

This section consists of results/findings and discussion about the TEFL methods used by EFL teachers to the elementary students of NCIPS in Indonesia. Here, we present the data gained and discuss the result.

Table 1

Interview Data of EFL Teacher 1

\begin{tabular}{|c|c|c|c|}
\hline \multirow{2}{*}{ No } & \multirow{2}{*}{ Questions } & Answers & \multirow{2}{*}{ Reasons } \\
\hline & & Yes No & \\
\hline 1 & $\begin{array}{l}\text { There are several methods of teaching a foreign } \\
\text { language. Those methods are Grammar Translation } \\
\text { Method (GTM), The Direct Method, The Audio-Lingual }\end{array}$ & $\sqrt{ }$ & $\begin{array}{l}\text { The method is the Direct Method. I use this method because } \\
\text { most of my students understand English well and it is useful for } \\
\text { them to practice English every day during the lesson }\end{array}$ \\
\hline
\end{tabular}
Language Learning (CLL) and The Total Physical Response (TPR). Do You use at least one method of the teaching methods above?

2 Do You think that method is very important in teaching English?

3 Do You usually use more than one method in each $\sqrt{ }$ teaching activity?

4 Do you think that every method has its advantages and $\quad \sqrt{ }$ disadvantages?

5 Do you think that an appropriate method will help students in understanding the material being taught?

6 Is the method used based on the curriculum of this school?

7 Do you sometimes encounter difficulties in using a method?

8 Do you think that teaching English for elementary students is easier than teaching English for Junior high school and Senior High school?

9 In teaching English as foreign language in this school, do you prefer speaking Bahasa Indonesia rather than speaking English?

This method (Direct Method) brings the teacher and students in an English atmosphere in the class. I try to find the simplest and familiar vocabularies. The students have to answer in English too.

It is the GTM (Grammar Translation Method). I use the Grammar Translation Method when I teach new materials that I know those are difficult for them. I also use this method when I teach about the culture of Indonesia that has to be explained well and easily understood. When they have understood it, I will explain it in English.

Of course, both of these methods have some advantages. For examples, the DM is very suitable with the characteristic of our school. The native language (Bahasa Indonesia) is forbidden in the class so the students will always hear English. The Advantages of using GTM: Students can understand grammar and directly compare it to Indonesian, so they will understand well the core of the material.

In teaching the material, I always use GTM so it is easier to be understood by students.

We use two curriculums. They are the National curriculum and Cambridge curriculum. So, we use Grammar Translation Method in teaching National Curriculum and we use both Grammar Translation Method and Direct Method in teaching Cambridge Curriculum.

$\sqrt{ } \quad$ So far so good. I get no difficulties in using these methods because these methods are suitable for our school and the students.

$\checkmark \quad$ For myself, I like children and I have trained myself to be closer to children. In teaching primary students, I always use some 'ava' and they really enjoy it.

$\sqrt{ } \quad$ I prefer to speak English rather than Indonesian. We try to create English atmosphere in the school. We ask students to communicate in English because as a language, it has to be spoken. By speaking we will try to improve or enrich our students in speaking, writing, reading and listening. 
10 Do you have other methods in teaching English for $\sqrt{ } \quad$ Yes it is. To check my students' understanding, I always make students in this school? If yes, what is it? quiz, playing game especially in teaching vocabularies.

EFL Teacher 1 (ET1), as shown in Table 1, explained that T1 used Direct Method in delivering TEFL class. Besides, s/he also used GTM. Based on ET1's explanation, those two methods were appropriate for teaching EFL for children. Next, it is presented interview data of Teacher 2.

Table 2

Interview Data of EFL Teacher 2

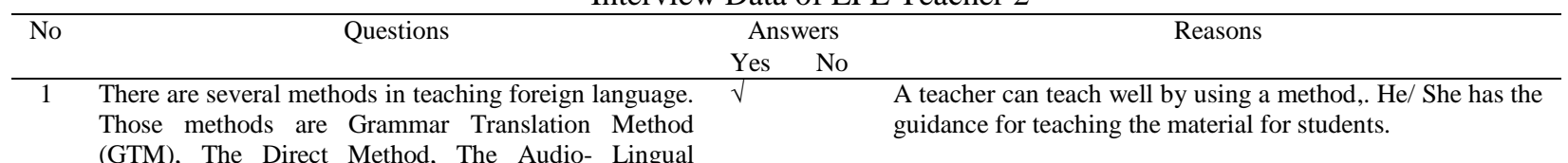

(GTM), The Direct Method, The Audio- Lingual

Method, The Silent Way, Sugestopedia, Community Language Learning (CLL) and The Total Physical Response (TPR). Do You use at least one method of the teaching methods above?

2 Do You think that method is very important in teaching $\sqrt{ }$ English?

3 Do You usually use more than one method in each $\sqrt{ }$ teaching activity?

4 Do you think that every method has its advantages and $\sqrt{ }$ disadvantages?

5 Do you think that appropriate method will help students $\sqrt{ }$ in understanding the material being taught?

6 Is the method used based on the curriculum of this $\sqrt{ }$ school?

7 Do you sometimes encounter difficulties in using a $\sqrt{ }$ method?

8 Do you think that teaching English for the elementary students is easier than teaching English for the Junior high school and Senior High school?

9 In teaching English as foreign language in this school, do you prefer speaking Bahasa Indonesia rather than speaking English?

10 Do you have other methods in teaching English for students in this school? If yes, what is it?

Without method, teaching and learning process don't go well. The teacher (I) will teach without guidance.

When I teach using Direct Method, the students will find hard to understand. I solve this problem by using another method, namely Grammar Translation Method.

Of course every method has its own advantages and disadvantages. For example Direct Method.

Of course by using the appropriate method, the students will be easier to understand the material. The teacher knows what the students need.

We use two curriculums, they are National curriculum and Cambridge curriculum so, we use Grammar Translation Method in teaching kurnas (National curriculum) and for teaching the Cambridge curriculum we use both Grammar Translation Method and Direct Method.

The problem in teaching elementary students is that the students will get difficulties if we teach by using difficult words in the books. That even though we use a method, we have to adapt the material we teach.

$\sqrt{ } \quad$ Teaching elementary students is not easy. Sometimes we as teachers have to simplify the materials which are too complicated for the students. They will ask and ask until we explain it with simple words and they understand.

$\sqrt{ } \quad$ I speak English more than Bahasa Indonesia, because when I give test, I use all English. Not only for the test but also during teaching and learning process inside the classroom.

$\sqrt{ } \quad$ No I don't

EFL Teacher 2 (ET2) stated that as their school used two curriculums, then ET2 would use Grammar Translation Method in teaching National Curriculum of Indonesia while the combination of Grammar Translation Method and Direct Method were applied in teaching Cambridge Curriculum. The next data of interview is displayed as follows.

Table 3

Interview Data of EFL Teacher 3

\begin{tabular}{|c|c|c|c|}
\hline \multirow[t]{2}{*}{ No } & \multirow[t]{2}{*}{ Questions } & Answers & \multirow[t]{2}{*}{ Reasons } \\
\hline & & Yes No & \\
\hline 1 & $\begin{array}{l}\text { There are several methods in teaching foreign } \\
\text { language. Those methods are Grammar Translation } \\
\text { Method (GTM), The Direct Method, The Audio- } \\
\text { Lingual Method, The Silent Way, Sugestopedia, }\end{array}$ & $\sqrt{ }$ & $\begin{array}{l}\text { The method of teaching refers to the regular ways or orderly } \\
\text { procedures employed by the teacher in guiding the pupils or students } \\
\text { in order to accomplish the aims of the learning process. }\end{array}$ \\
\hline
\end{tabular}

Anabokay, Y., \& Suryasa, I. W. (2019). TEFL Methods in Indonesia. International Journal of Linguistics,

Literature and Culture, 5(2), 13-24.

https://doi.org/10.21744/ijllc.v5n2.612 
Community Language Learning (CLL) and The Total Physical Response (TPR). Do You use at least one method of the teaching methods above?

2 Do You think that method is very important in $\sqrt{ }$ teaching English?

3 Do You usually use more than one method in each teaching activity?

4 Do you think that every method has its advantages $\sqrt{ }$ and disadvantages?

5 Do you think that appropriate method will help $\sqrt{ }$ students in understanding the material being taught?

6 Is the method used based on the curriculum of this school?

7 Do you sometimes encounter difficulties in using a $\sqrt{ }$ method?

8 Do you think that teaching English for the elementary students is easier than teaching English for the Junior high school and Senior High school?

9 In teaching English as foreign language in this school, do you prefer speaking Bahasa Indonesia rather than speaking English?

10 Do you have other methods of teaching English for students in this school? If yes, what is it?
Method involves regular steps to guide the mental process of learner in mastering the subject matter. A method helps students to understand materials. Furthermore, a method could stimulate the thinking of students. Method is the key of teaching and learning process.

By using more than one method in teaching students will be more stimulating so they are not boring.

No one has proven that one method is superior to another in every situation, so every method has its advantages and its disadvantages.

By using an appropriate method, students will be helped in understanding the material being taught.

That is important for a school to have a method based on the curriculum of the school itself.

Sometimes when I teach using a method I found the situation in classroom is not good, it means they have problem in understanding material being taught.

$\sqrt{ }$ Teaching English for elementary students is difficult because sometimes they cannot follow the teaching and learning process like what is expected by teacher, especially about the grammar.

I mix these two languages in order to help students understand the material.

$\sqrt{ } \quad$ No, I haven't.

EFL Teacher 3 (ET3) stated that she had no special method in teaching EFL. ET3 has combined all methods in teaching EFL. Furthermore, ET3 stated that s/he mixed the use of Bahasa and English when s/he teaches EFL. Furthermore, we have also conducted classroom observation. The results of the observations are displayed in the following tables.

Table 4

English Teaching Methods Used in Teaching EFL Students of Grade One

\begin{tabular}{ccccccc}
\hline $\begin{array}{c}\text { Methods } \\
\text { Meeting }\end{array}$ & GTM & $\begin{array}{c}\text { Direct } \\
\text { Method }\end{array}$ & $\begin{array}{c}\text { Audio- } \\
\text { Lingual } \\
\text { Method }\end{array}$ & $\begin{array}{c}\text { The Silent } \\
\text { Way }\end{array}$ & $\begin{array}{c}\text { Suges- } \\
\text { topedia }\end{array}$ & CCL \\
\hline $1^{\mathrm{ST}}$ & $\sqrt{ }$ & - & - & - & - & - \\
$2^{\mathrm{ND}}$ & $\sqrt{ }$ & $\sqrt{ }$ & - & - & - & - \\
$3^{\mathrm{RD}}$ & $\sqrt{ }$ & $\sqrt{ }$ & - & - & - & - \\
\hline
\end{tabular}

Table 5

English Teaching Methods Used in Teaching EFL Students of Grade Two A

\begin{tabular}{ccccccc}
\hline $\begin{array}{c}\text { Methods } \\
\text { Meeting }\end{array}$ & GTM & $\begin{array}{c}\text { Direct } \\
\text { Method }\end{array}$ & $\begin{array}{c}\text { Audio- } \\
\text { Lingual } \\
\text { Method }\end{array}$ & $\begin{array}{c}\text { The Silent } \\
\text { Way }\end{array}$ & $\begin{array}{c}\text { Suges- } \\
\text { topedia }\end{array}$ & CCL \\
\hline $1^{\mathrm{ST}}$ & $\sqrt{ }$ & $\sqrt{ }$ & - & - & - & - \\
$2^{\mathrm{RD}}$ & - & $\sqrt{ }$ & - & - & - & - \\
$3^{\mathrm{RD}}$ & $\sqrt{ }$ & $\sqrt{ }$ & - & - & - & - \\
\hline
\end{tabular}

Table 6

English Teaching Methods Used In Teaching EFL Students of Grade Two (B)

\begin{tabular}{ccccccc}
$\begin{array}{c}\text { Methods } \\
\text { Meeting }\end{array}$ & GTM & $\begin{array}{c}\text { Direct } \\
\text { Method }\end{array}$ & $\begin{array}{c}\text { Audio- } \\
\text { Lingual } \\
\text { Method }\end{array}$ & $\begin{array}{c}\text { The Silent } \\
\text { Way }\end{array}$ & $\begin{array}{c}\text { Suges- } \\
\text { topedia }\end{array}$ \\
\hline $1^{\text {ST }}$ & $\sqrt{ }$ & $\sqrt{ }$ & - & - & - & CCL \\
$2^{\text {ND }}$ & $\sqrt{ }$ & $\sqrt{ }$ & - & - & - & - \\
$3^{\mathrm{RD}}$ & $\sqrt{ }$ & $\sqrt{ }$ & - & - & - & - \\
\hline
\end{tabular}


Table 7

English Teaching Methods Used In Teaching EFL Students of Grade Three

\begin{tabular}{ccccccc}
\hline $\begin{array}{c}\text { Methods } \\
\text { Meeting }\end{array}$ & GTM & $\begin{array}{l}\text { Direct } \\
\text { Method }\end{array}$ & $\begin{array}{c}\text { Audio- } \\
\text { Lingual } \\
\text { Method }\end{array}$ & $\begin{array}{c}\text { The Silent } \\
\text { Way }\end{array}$ & $\begin{array}{l}\text { Suges- } \\
\text { topedia }\end{array}$ & CCL \\
\hline $1^{\mathrm{ST}}$ & $\sqrt{ }$ & - & - & - & - & - \\
$2^{\mathrm{ND}}$ & $\sqrt{ }$ & $\sqrt{ }$ & - & - & - & - \\
$3^{\mathrm{RD}}$ & $\sqrt{ }$ & $\sqrt{ }$ & - & - & - & - \\
\hline
\end{tabular}

Table 8

\begin{tabular}{ccccccc}
\multicolumn{7}{c}{ English Teaching Methods Used In Teaching EFL Students of Grade Four } \\
$\begin{array}{c}\text { Methods } \\
\text { Meeting }\end{array}$ & GTM & $\begin{array}{c}\text { Direct } \\
\text { Method }\end{array}$ & $\begin{array}{c}\text { Audio- } \\
\text { Lingual } \\
\text { Method }\end{array}$ & $\begin{array}{c}\text { The Silent } \\
\text { Way }\end{array}$ & $\begin{array}{c}\text { Suges- } \\
\text { topedia }\end{array}$ & CCL \\
\hline $1^{\mathrm{ST}}$ & $\sqrt{ }$ & $\sqrt{ }$ & - & - & - & - \\
$2^{\mathrm{ND}}$ & $\sqrt{ }$ & $\sqrt{ }$ & - & - & - & - \\
$3^{\mathrm{RD}}$ & $\sqrt{ }$ & $\sqrt{ }$ & - & - & - & - \\
\hline
\end{tabular}

The data have shown that the English Teachers of grade 2 A, grade 2 B, grade 3 and grade 4 used similar methods in teaching EFL. Those methods were the Grammar Translation Method and Direct Method. These two methods were usually used together in each meeting as seen in table 4, table 5, table 6, table 7 and table 8 .

Grammar Translation Method was used especially for reading comprehension, writing activities and vocabularies learning while Direct Method was used in speaking and listening. They used two methods in order to avoid students from feeling bored in the classroom and to help the student in mastering the materials being taught. In using the Grammar Translation Method, the teachers gave students the list of difficult words with the meaning in Bahasa Indonesia and asked the student to memorize those difficult words. Students were pushed to memorize them. For example, the teacher of grade 4 gave her students about 100 difficult words and ordered them to memorize the words at home as their homework. The next meeting, the teacher called each student to come in front of the classroom and presented their result. There were several students who were punished because they only memorized less than 15 words.

The other way they used the Grammar Translation Method was by asking students to translate the reading from English to Bahasa Indonesia. Students must bring their own dictionaries to look up the meanings in Bahasa Indonesia. Grammar Translation Method was also used as a combination with the Direct Method. Next, the Direct Method was used in almost every meeting and situation. It was based on the value of the school as an International school which used English as their leading language. In this school, the teachers spoke in simple English to the students, all notifications were written in English, the timetables were also written in English.

The teachers also used the Grammar Translation Method and Direct Method based on the school curriculums. Table 2 and table 3 show that the school used two curriculums; they were the National curriculum and Cambridge curriculum. When the teachers taught speaking and listening to they used Direct Method based on the Cambridge curriculum but when they taught reading and writing they used the Grammar Translation Method proposed in the National Curriculum. Furthermore, in using the Direct Method and Grammar Translation Method, there were some advantages and disadvantages.

Based on the classroom research, the EFL teachers of NCIPS said that there were some advantages and disadvantages of the Direct Method for students of NCIPS. They were as follows. First, the advantages were (1) the students have more chance to practice English especially for listening and speaking skills; (2) the students are encouraged to think in English; (4) the students can learn to express themselves directly in English without the need to translate their thought or idea from Bahasa Indonesia into English, and (5) the students are easily acquiring English. Second, the disadvantages were (1) sometimes the students, especially the students of grade one did not understand what teachers were saying, so they could not do what was ordered by the teachers. For example there was in the classroom when a teacher ordered a student to go to the principal's room but the student did not understand, so he kept sitting in the classroom; (2) the students became more difficult in understanding the content being taught because they had to 'work twice', that was to understand the English first after that to get the content. For example, when the students were learning about simple past tense, they had to understand the English which was spoken by the teacher before they know how to construct a sentence of simple past tense; and (3) there was a misunderstanding especially for the students to their teachers.

Next, the EFL teachers of NCIPS stated that there were also some advantages and disadvantages of the Grammar Translation Method for students of NCIPS. They were as follows. First, the advantages were (1) the students are able

Anabokay, Y., \& Suryasa, I. W. (2019). TEFL Methods in Indonesia. International Journal of Linguistics,

Literature and Culture, 5(2), 13-24. https://doi.org/10.21744/ijllc.v5n2.612 
to memorize many vocabularies; (2) the students can learn a content being taught easily because they know the meaning in Bahasa; (3) the students are good in translation works. On the other hand, the advantages of the method, based on the teachers experiences were, (1) learning is primary from teacher to students with very little students' interaction and initiation in the classroom; (2) the students only did what text was ordered to be translated without having any initiation to do something they like in learning; and (3) the students easily feeling bored because almost every reading has to be translated into Bahasa.

\section{Conclusion}

Having examined the data as described above, it is concluded that; (1) The methods used by the elementary teachers of NCIPS were Direct Methods and Grammar Translation Method. Those methods were mostly used together in every meeting; (2) The methods were used based on the school curriculums. The curriculums were Cambridge curriculum and the National Curriculum. In teaching Cambridge curriculum, the Direct Method was used more than the Grammar Translation Method, while in teaching National curriculum, the Grammar Translation Method was more used rather than the Direct Method; (3) Beside the methods were used based on the school curriculums, they were also used based on the language skills being taught. For example: Grammar Translation Method was used especially for reading comprehension, writing activities and vocabularies learning while Direct Method was used especially in speaking and listening; (4)The way teachers used the methods was not exactly the same as the related theory about the principles of theories but it was used based on the students' condition or students' ability. For example, in using Direct Method, teachers did not speak English at all as the principles of Direct Method which forbid the use of mother tongue and translation but the teachers also spoke in Bahasa Indonesia to clarify the meaning. In other words, teachers combined this Direct Method with the Grammar Translation Method.

Dealing with the teachers' methods in teaching English to the elementary students in Indonesia, we suggest that they may improve their creativities in using the methods so the learning process will be more fun and exciting for students. Besides, they have to improve their way in using Direct Method and Grammar Translation Method, the teachers are also suggested to use other methods like The Audio-Lingual Method, The Silent Way, Suggestopedia, Community Language Learning (CLL) and The Total Physical Response (TPR) to avoid students from getting bored. Especially for Community Language Learning (CLL), we suggest the teachers use this method as the status of NCIPS as an International school which uses English as its daily language. This suggestion is based on our finding which showed that most of the students there only tried to speak English to their teachers while in their own community, between friends, they did not speak English. At this point, CLL is very recommended for the Indonesia case. The last, we suggest the teachers use more media like videos or pictures and games in order to make English teaching and learning activities better.

\section{Conflict of interest statement and funding sources}

The authors declared that they have no competing interest. The study was financed by themselves.

\section{Statement of authorship}

The authors have a responsibility for the conception and design of the study. The authors have approved the final article.

\section{Acknowledgments}

We would like to thank IJLLC journal since the journal has facilitated us in publishing our research work. 


\section{References}

Castagnaro, P. J. (2006). Audiolingual method and behaviorism: From misunderstanding to myth. Applied linguistics, 27(3), 519-526.

Chang, S. C. (2011). A contrastive study of grammar translation method and communicative approach in teaching English grammar. English language teaching, 4(2), 13.Larsen-Freeman, Diana. (2008). Techniques and Principles in Language Teaching. Oxford: Oxford University Press. Larsen freeman-techniques-and-principles-in-languageteachinghttps://www.slideshare.net/ahlam7dreams/larsen-freemantechniquesandprinciplesinlanguageteaching

Echevarria, J., Vogt, M., \& Short, D. (2008). Making content comprehensible for English learners: The SIOP model.

Howatt, A. P. R. (1984). Language teaching traditions: 1884 revisited. ELT Journal, 38(4), 279-282.

Kharismawati, R. (2014). Suggestopedia method in the teaching and learning process. RETAIN, 2(1).

La Forge, P. G. (1971). Community language learning: A pilot study. Language Learning, 21(1), 45-61.

Larsen-Freeman, Diana. (1986). Techniques and Principles in Language Teaching. Brattleboro, Vermont: Oxford University Press.

Lauder, A. (2010). The status and function of English in Indonesia: A review of key factors. Hubs-Asia, 10(1).

Mistar, J. (2005). Teaching English as a foreign language (TEFL) in Indonesia. Teaching English to the world: History, curriculum, and practice, $75-85$.

Moussu, L., \& Llurda, E. (2008). Non-native English-speaking English language teachers: History and research. Language teaching, 41(3), 315-348.

Richards, J. C., \& Rodgers, T. S. (2014). Approaches and methods in language teaching. Cambridge university press.

Salinas, C., Fránquiz, M. E., \& Guberman, S. (2006). Introducing historical thinking to second language learners: Exploring what students know and what they want to know. The Social Studies, 97(5), 203-207.

Anabokay, Y., \& Suryasa, I. W. (2019). TEFL Methods in Indonesia. International Journal of Linguistics, Literature and Culture, 5(2), 13-24. https://doi.org/10.21744/ijllc.v5n2.612 


\section{Biography of Authors}

Yanrini Martha Anabokay is a lecturer as well as a researcher in Universitas Persatuan
Guru 1945, Kupang- NTT, Indonesia. She is currently the head of English Study Program
at the University. She lives in Jalan Pandan RT 15 RW 4 Airnona Kecamatan Kota Raja,
Kota Kupang- NTT, Indonesia. She has finished her Master Degree on Linguistics in
Universitas Nusa Cendana. Her interests are in education and linguistics field. She can
be contacted in 085333166441(mobile).
Email: anabokayrini@gmail.com

